\title{
Bartłomiej Oszkinis
}

Uniwersytet w Białymstoku e-mail: b.oszkinis@uwb.edu.pl telefon: +48 857457193

DOI: $10.15290 / \mathrm{mhi} .2014 .13 .02 .11$

\section{Pojęcie konkubinatu w świetle polskiej doktryny i orzecznictwa}

\author{
SUMMARY \\ Concubinage - the meaning of the term in the light of Polish juridical doctrine \\ and court decisions
}

Accepted by some groups of people and condemned by another ones informal relationships have been recognized but not defined by the Polish legislator. In the absence of the legal definition it is a task of legal scholars and judges to establish what kind of relationships can be classified as falling under the heading of the equivocal expressions used by the legislator in legal acts. Traditionally, concubinage is deemed as a relationship of that kind. However, it is highly controversial how this type of informal union should be defined. In the first part of this paper the author presents opinions of the legal scholars and judges on the constitutive features of concubinage and proposed definitions of the term. In the second part he analyzes presented data and proposes a typological definition of concubinage which on the ground of Polish legal tradition can be described as a heterosexual, stable, (not necessarily) notorious relationship of two (or more) people who live together (or not). The cohabitants cannot be legally married and have to form a life communion (characterized by the existence of emotional, physical and economic sensu largo bonds). The union have to be seen by them as an autotelic value and cannot be (even potentially) against the law.

Key words: concubinage, partnership, legal definition, family law, Polish law

Słowa kluczowe: konkubinat, związek pozamałżeński, definicja prawna, prawo rodzinne, prawo polskie

Od zarania dziejów małżeństwu towarzyszą alternatywne postacie ludzkiego współżycia. O ile jednak małżeństwo jest względnie stałe w swej strukturze, o tyle związki nieformalne przybierają coraz to nowe formy wraz ze zmieniającymi się realiami życia ${ }^{1}$. Przy czym nie znaczy to, a przynajmniej

1 F. Hartwich, Zwiazki partnerskie. Aspekty prawne, Warszawa 2011, s. 17. 
nie musi oznaczać, że formy dotychczasowe ulegają zanikowi. Owe alternatywne formy pożycia większość ludzi intuicyjnie (przynajmniej w niektórych przypadkach) określa mianem konkubinatu. Termin ten, co należy wskazać antycypując dalsze wywody, występuje także na gruncie doktryny prawa oraz orzecznictwa sądowego. Warto zatem zastanowić się nad jurydycznym rozumieniem owego pojęcia, jako że zakwalifikowanie albo brak klasyfikacji danego związku jako konkubinatu pociągać może dla tworzących go osób określone konsekwencje prawne.

Rozważania na temat pojęcia konkubinatu w doktrynie prawa jak i orzecznictwie zacząć należy od zasygnalizowania, iż w ustawodawstwie polskim, $\mathrm{w}$ przeciwieństwie np. do francuskiego ${ }^{2}$, pojęcie to nie zostało zdefiniowane. Co więcej, jak podkreśla się $\mathrm{w}$ literaturze, $\mathrm{w}$ polskim języku prawnym termin ten $w$ ogóle nie występuje ${ }^{3}$. Zauważyć przy tym należy, iż na gruncie poprzednio obowiązującego stanu prawnego sformułowanie to zostało użyte w załącznikach $2 \mathrm{~b}$ oraz $2 \mathrm{c}$ do ustawy z 22 stycznia 1999 roku o ochronie informacji niejawnych ${ }^{4}$. W punkcie piątym obu ankiet bezpieczeństwa osobowego wypełniający zobowiązany był do wskazania określonych informacji na temat swojej małżonki/małżonka, przy czym w zawartej tam adnotacji wyjaśniono, iż punkt ów odnosi się także do konkubiny/konkubenta tudzież osoby o takim charakterze, pozostającej we wspólnym gospodarstwie domowym $\mathrm{z}$ osobą wypełniającą. $\mathrm{W}$ ankiecie bezpieczeństwa osobowego zawartej $\mathrm{w}$ załączniku do obecnie obowiązującej ustawy ${ }^{5} \mathrm{w}$ punkcie B, części II posłużono się sformułowaniem partner życiowy (partnerka życiowa) osoby sprawdzanej.

Zamiast analizowanego pojęcia, $\mathrm{w}$ języku prawnym używane są natomiast zwroty, które, jak wskazuje się w piśmiennictwie, stanowią odpowiedniki definiensa $\mathrm{w}$ doktrynalnej definicji konkubinatu ${ }^{6}$; chodzi mianowicie o: pozostawanie „faktycznie we wspólnym pożyciu” (np. art. 691 §1 k.c.7), pozostawanie „W faktycznym pożyciu" (art. 111 §3 ord. podat. ${ }^{8}$ ), pozostawanie „we wspól-

2 Zgodnie z art. 515 - 8. francuskiego kodeksu cywilnego z 21 marca 1804 r. (Code civil) - „konkubinat jest związkiem faktycznym, charakteryzującym się wspólnym, stałym i ciągłym pożyciem osób różnej albo tej samej płci, żyjących jak para", tekst ustawy dostępny na: http://www.legi france.gouv.fr/affichCode.do?cidTexte=LEGITEXT000006070721\&dateTexte=20140128 [25.01.2014].

3 M. Nazar, Konkubinat, [w:] System Prawa Prywatnego. Prawo rodzinne i opiekuńcze, red. T. Smyczyński, t. 11, Warszawa 2009, s. 909.

4 Tekst jednolity Dz. U. z 2005 r. Nr 196, poz. 1631 z późn zm.

5 Ustawa z 5 sierpnia 2010 r. o ochronie informacji niejawnych (Dz. U. Nr 182, poz. 1228).

6 M. Nazar, Konkubinat a małżeństwo - wybrane zagadnienia, [w:] Ksiega Jubileuszowa Profesora Tadeusza Smyczyńskiego, red. M. Andrzejewski, L. Kociucki, M. Łączkowska, A. N. Schulz, Toruń 2008, s. 220.

7 Ustawa z 23 kwietnia 1964 r. Kodeks cywilny (t.j. Dz. U. z 2014 r., poz. 121).

8 Ustawa z 29 sierpnia 1997 r. Ordynacja podatkowa (t.j. Dz. U. z 2012 r., poz. 749 z późn. zm.). 
nym pożyciu” (art. $115 \S 11$ k.k. ${ }^{9}$ ), pozostawanie „w faktycznym związku” (art. 6 pkt 14 u.p.s. ${ }^{10}$ ), pozostawanie „faktycznie we wspólnym pożyciu małżeńskim” (art. 15 ust. 3 u.p.b.m. ${ }^{11}$ ). Mając powyższe na uwadze, sformułowano tezę, iż próba stworzenia definicji konkubinatu ma znaczenie głównie doktrynalne, gdyż dla praktyki najważniejsze jest ustalenie znaczeń terminów ustawowych ${ }^{12}$. Stwierdzić jednak należy, iż termin ten jest powszechnie stosowany w orzecznictwie ${ }^{13}$, co więcej, bywa on utożsamiany $\mathrm{z}$,pozostawaniem w trwałym związku faktycznym”14 lub też wskazuje się, że np. termin „,wspólne pożycie" odnoszony jest wyłącznie do konkubinatu ${ }^{15}$. W związku z tym nie należy umniejszać znaczenia definicji konkubinatu nadając jej walor wyłącznie albo przynajmniej w przeważającym zakresie teoretyczny.

Mając powyższe na uwadze, należałoby przejść do przedstawienia typologicznych cech konkubinatu wyróżnianych przez przedstawicieli doktryny. Zanim to jednak nastąpi, warto choćby w ograniczonym zakresie odnieść się do pochodzenia tego terminu oraz jego rozumienia w potocznym języku polskim, gdyż stanowią one punkt wyjścia dla doktrynalnego i orzeczniczego rozumienia przedmiotowego pojęcia.

Wspomnianą skrótową prezentację zacząć należy od tego, iż termin „konkubinat" pochodzi od łacińskiego słowa concubinatus, powstałego z połączenia dwóch wyrazów: con - razem oraz cubare - leżeć ${ }^{16}$. W prawie rzymskim mianem tym określano trwałe współżycie mężczyzny z kobietą bez zamiaru pożycia małżeńskiego (tzw. affectio maritalis) ${ }^{17}$. Podobnie termin ten rozumiany jest obecnie - w powszechnym języku polskim. Słownik języka polskiego definiuje konkubinat jako „trwałe pożycie mężczyzny z kobietą bez zawarcia związku małżeńskiego"18.

Po zasygnalizowaniu powyższego należy przejść do wspomnianego na wstępie wskazania typologicznych cech konkubinatu, wymienianych w doktrynie.

Ustawa z 6 czerwca 1997 r. Kodeks karny (Dz. U. Nr 88, poz. 553 z późn. zm.).

Ustawa z 12 marca 2004 r. o pomocy społecznej (t.j. Dz. U. z 2012 r., poz. 182 z późn. zm.).

Ustawa z 26 października 1995 r. o niektórych formach popierania budownictwa mieszkaniowego (t.j. Dz. U. z 2013 r., poz. 255 z późn. zm.).

M. Nazar, Konkubinat, [w:] System..., s. 910.

Zob. przykładowe, acz obszerne zestawienie orzecznictwa, dokonane przez F. Hartwicha, Konkubinat - dylematy prawne, „Palestra” 2007, nr 3-4, s. 67, przyp. 51.

Zob. wyrok SA w Białymstoku z 23 lutego 2007 r., I ACa 590/06, LEX nr 259105.

Postanowienie SN z 7 lipca 2004 r., II KK 176/04, LEX nr 121668.

A. Markowski, R. Pawelec, Wielki słownik wyrazów obcych i trudnych, Warszawa 2001, s. 402.

W. Osuchowski, Rzymskie prawo prywatne. Zarys wykładu, Warszawa 1981, s. 213.

Zob. np. Słownik języka polskiego. t. I, A-K, red. H. Szkiłądź, S. Bik, C. Szkiłądź, Warszawa 1993, s. 991; Słownik Języka Polskiego PWN: http://sjp.pwn.pl/szukaj/konkubinat [24.01.2014]. 
Pierwszą z nich stanowi „brak uznawanej przez prawo więzi małżeńskiej". Cecha ta wynika z istoty konkubinatu jako związku polegającego na faktycznym (niesformalizowanym) pożyciu partnerów ${ }^{19}$. Dlatego też niemożliwe jest jego zaistnienie między małżonkami pozostającymi w separacji orzeczonej przez sąd ${ }^{20}$. Może on natomiast istnieć np. między byłymi małżonkami, osobami z tzw. małżeństw nieistniejących, czy też zawartych jedynie $\mathrm{w}$ formie wyznaniowej, nieuznawanej przez prawo cywilne ${ }^{21}$. Szczególnie interesujące są dwa ostatnie przypadki.

Małżeństwo nie zostaje zawarte, jeżeli nie zostaną spełnione materialne przesłanki wskazane $\mathrm{w}$ art. 1 k.r.o. ${ }^{22} \mathrm{~W}$ takiej sytuacji związek ten $\mathrm{w}$ świetle prawa będzie konkubinatem, nawet jeżeli zostanie sporządzony akt małżeństwa (art. 2 k.r.o.). Skutkiem tego będzie brak powstania między stronami więzi rodzinno-prawnych, normowanych przez k.r.o.

Jak wskazuje się w doktrynie, w szczególnej sytuacji znajdują się niedoszli małżonkowie, którzy nie zdają sobie sprawy z nieistnienia małżeństwa z powodu złożenia oświadczeń woli o wstąpieniu w związek małżeński przed niewłaściwą osobą ${ }^{23}$. W związku z faktem, iż ustawodawca nie wprowadził przepisów łagodzących rygoryzm skutków niezawarcia małżeństwa w piśmiennictwie, podnosi się, iż nie ma podstaw do stosowania per analogiam $\mathrm{w}$ stosunku do takich osób przepisów k.r.o. o małżeństwie, pochodzeniu dzieci i stosunkach majątkowych między małżonkami. Osoby takie winny zostać uznane, w zależności od okoliczności danego przypadku, rzecz jasna, za pozostające (faktycznie) we wspólnym (małżeńskim) pożyciu lub faktycznym związku w rozumieniu przepisów, które wiążą określone skutki prawne $\mathrm{z}$ tak ujętymi stanami faktycznymi ${ }^{24}$. Pogląd ten wydaje się trafny.

Jeszcze ciekawszy jest drugi ze wskazanych przypadków - małżeństwa wyznaniowe nieuznawane przez prawo cywilne. Chodzi tu o związki zawarte jedynie $\mathrm{w}$ formie wyznaniowej $\mathrm{w}$ okresie, gdy wyłączną formą zawarcia małżeństwa, w myśl prawa polskiego, była forma cywilna, tj. od 1 stycznia 1946 do 15 września 1998 roku $^{25}$. Odnośnie do tego typu związków pojawiły się

19 M. Nazar, Konkubinat a małżeństwo..., s. 223; zob. też: F. Hartwich, Zwiazki partnerskie..., s. 73-74; wyrok SA w Katowicach z 4 października 2012 r., II Aka 349/12, LEX nr 1236422; wyrok SN z 31 marca 1988 r., I KR 50/88, LEX nr 20315; wyrok SN z 6 grudnia 2007 r., IV CSK 301/07, LEX nr 361309.

M. Nazar, Konkubinat a małżeństwo..., s. 223.

Ibidem.

Ustawa z 25 lutego 1964 r. Kodeks rodzinny i opiekuńczy (t.j. Dz. U. z 2012 r., poz. 788).

M. Nazar, Konkubinat a mał̇̇eństwo..., s. 231.

Ibidem, s. 231-232.

1 stycznia 1946 r. wszedł w życie dekret z 25 września 1945 r. Prawo małżeńskie (Dz. U. Nr 48, poz. 270), w którym określono, że jedyną prawnie uznawaną formą zawarcia małżeństwa jest forma cywilna. Natomiast 15 września 1998 r. weszła w życie ustawa z 24 lipca 1998 r. o zmianie 
dwa interesujące orzeczenia. W pierwszym $\mathrm{z}$ nich ${ }^{26}$ NSA w Warszawie orzekł o zastosowaniu art. 20 ust. 3 tzw. ustawy kombatanckiej ${ }^{27} \mathrm{w}$ stanie faktycznym, w którym z roszczeniami na podstawie wspomnianej ustawy wystąpiła kobieta podająca jako podstawę faktyczną swych roszczeń zawarcie w 1950 roku małżeństwa wyłącznie w formie wyznaniowej ${ }^{28}$. Sąd wywiódł, iż w okresie, w którym małżeństwo zostało zawarte, przekonanie, że tylko cywilna forma wywołuje skutki przewidziane prawem polskim, nie była powszechna ani ugruntowana $\mathrm{w}$ świadomości społeczeństwa ${ }^{29}$. W związku z tym NSA uznał, że konkubinat, u którego źródeł leżało przekonanie o tym, iż związek li tylko wyznaniowy powoduje skutki przewidziane prawem polskim, winien zostać uznany za "konkubinat kwalifikowany" („małżeństwo faktyczne”). Ponadto sąd uznał za niekonsekwencję ze strony ustawodawcy pozostawienie wśród konkubinatów dotychczasowych małżeństw wyznaniowych zawartych w latach 1947-1997, gdyż w obecnym stanie prawnym formy te są równoważne. W związku z tym NSA wyraził pogląd, iż w przepisach ustawy kombatanckiej pojawiła się luka $\mathrm{w}$ prawie, uzasadniająca analogiczne stosowanie jej przepisów, przyznających określone uprawnienia wdowom (ze związków zawartych w formie cywilnej) po kombatantach, do wdów ze związków wyznaniowych zawartych przed rokiem 1998. W drugim zaś ze wspomnianych wyroków ${ }^{30}$ SN stwierdził, iż z unormowania kanonów 1055 §1 oraz 1057 §2 kodeksu prawa kanonicznego statuują małżeństwo jako zupełną i nieodwołalną wspólnotę całego życia. Ponadto sąd wywiódł, że jakkolwiek małżeństwo sakramentalne nie uzyskuje sankcji przymusu państwowego (także w dziedzinie wzajemnej alimentacji), nie można jednak traktować go jako okoliczności nieistniejącej czy też konkubinatu. Wyroki te poddane zostały krytyce ${ }^{31}$, słusznej, jak się wydaje. Odnośnie do pierwszego z przytoczonych orzeczeń wskazano, iż

ustawy - Kodeks rodzinny i opiekuńczy, Kodeks postępowania cywilnego, Prawo o aktach stanu cywilnego, ustawy o stosunku Państwa do Kościoła Katolickiego w Rzeczpospolitej Polskiej oraz niektórych innych ustaw (Dz. U. Nr 117, poz. 757), która dopuściła możliwość zawierania małżeństw $\mathrm{w}$ formie wyznaniowej ze skutkami określonymi w prawie polskim (zob. art. 1 §2 oraz art. 3 k.r.o).

Wyrok NSA w Warszawie z 12 kwietnia 2000 r., V SA 1512/99, LEX nr 49058.

Ustawa z 24 stycznia 1991 r. o kombatantach oraz niektórych osobach będących ofiarami represji wojennych i okresu powojennego (t.j. Dz. U. z 2012 r., poz. 400).

Zgodnie z art. 20 ust. 3 "ustawy kombatanckiej” uprawnienia przyznane kombatantom w ust. 2 tegoż artykułu przysługują także wdowom lub wdowcom - emerytom i rencistom oraz osobom pobierającym uposażenie $\mathrm{w}$ stanie spoczynku lub uposażenie rodzinne pozostałym po kombatantach i innych osobach uprawnionych.

Unormowania zakazujące duchownym, pod groźbą sankcji karnej, udzielania ślubów wyznaniowych osobom, które nie zawarły uprzednio małżeństwa w formie cywilnej obowiązywały dopiero od roku 1958 (zniesione zostały w 1989 r. na mocy art. 74 ust. 12 ustawy z 17 maja 1989 r. o stosunku Państwa do Kościoła Katolickiego w Rzeczypospolitej Polskiej (t.j. Dz. U. z 2013 r., poz. 1169).

Wyrok SN z 27 listopada 1998 r., II CKN 31/98, LEX nr 37571.

M. Nazar, Konkubinat a małżeństwo..., s. 229-231. 
przedstawiona przez NSA ewolucja przepisów prawa małżeńskiego uzasadnia co najwyżej postulat stosownej nowelizacji ustawy ${ }^{32}$, w przypadku zaś drugiego podniesiono, iż nie doszło $\mathrm{w}$ prawie polskim do poszerzenia listy zdarzeń powodujących powstanie zobowiązań niezupełnych (naturalnych) o fakt utworzenia wyznaniowej wspólnoty małżeńskiej33. Natomiast same związki zawarte jedynie $\mathrm{w}$ formie wyznaniowej, jakkolwiek można by je określić mianem „małżeństw faktycznych" ze względu na ich formalną jawność (notoryjność), ułatwiającą dowodzenie faktów i mającą istotne znaczenie dla rozstrzygania spraw partnerów, z punktu widzenia prawa winny być jednak traktowane jak "zwykłe" konkubinaty, a "faktyczni małżonkowie" jak konkubenci ${ }^{34}$. Pogląd ten podziela większość doktryny ${ }^{35}$.

Nieformalny charakter związku jako cecha konkubinatu nie budzi w doktrynie $^{36}$ jak i orzecznictwie wątpliwości, jednak cechę tę posiadają także inne wspólnoty partnerskie, np. wspólnoty mieszkaniowe osób spokrewnionych lub zaprzyjaźnionych i prowadzących wspólne gospodarstwo domowe, dlatego też, by wyróżnić spośród nich konkubinat, należy odnieść się do jego pozostałych cech, ich konfiguracji i natężenia ${ }^{37}$.

Kolejną cechą konkubinatu wskazywaną w literaturze i orzecznictwie jest istnienie wspólnoty życiowej, która to wspólnota charakteryzuje się splotem życiowych interesów osobistych i majątkowych partnerów ${ }^{38}$. Wspólnotę tę statuuje, według szeroko akceptowanego poglądu, istnienie między partnerami więzi emocjonalnej, fizycznej, gospodarczej oraz wspólne ich zamieszkiwanie ${ }^{39}$. Co ważne, istnienie tychże czynników oznacza, że między stosunkami osobistymi i majątkowymi zachodzi współzależność, nie zaś paralelność typowa dla mniej rozległych i nie tak spójnych wspólnot partnerskich ${ }^{40}$.

Więź gospodarcza, w myśl powyższego stanowiska, wyrażać się powinna przynajmniej w prowadzeniu wspólnego gospodarstwa domowego, może po-

32 Ibidem, s. 229-230. Ponadto wskazuje się, iż można by ewentualnie bronić także poglądu o aksjologicznej zasadności rozszerzającej wykładni art. 19 i 20 ustawy kombatanckiej, tak by przywileje i korzyści przyznawane wdowom i wdowcom po kombatantach mogły obejmować także ich partnerów ze związków faktycznych, ibidem, s. 230.

Ibidem, 227-229.

Tak S. Paździor, Konkubinat w prawie kanonicznym oraz polskim prawie cywilnym, „Roczniki Nauk Prawnych" 2007, t. XVII (2), s. 184.

36 Zob. np. B. Paul, Konkubinat, "Jurysta” 2002, nr 7-8, s. 8; A. Szlęzak, Wybrane zagadnienia prawnorodzinne konkubinatu, „Ruch Prawniczy Ekonomiczny i Socjologiczny” 1992, z. 3, s. 27, przyp. 1; S. Paździor, op. cit., s. 183; A. Zieliński, Zarys instytucji konkubinatu, „Palestra” 1983, nr 12, s. 12. Ibidem, s. 31; zob. też np. wskazany w przyp. 19 wyrok SN z 6 grudnia 2007 r.

Zob. M. Nazar, Rozliczenia majątkowe..., s. 32-33; zob. też np. wskazany w przyp. 19 wyrok SN z 31 marca 1988 r. 
legać także na prowadzeniu wspólnej działalności zarobkowej, wspólnym nabywaniu nieruchomości, jak i na obustronnych świadczeniach ponoszonych przez partnerów, tak osobistych, jak i majątkowych, służących zaspokojeniu bieżących lub długofalowych potrzeb wspólnoty ${ }^{41}$.

Więź emocjonalną [zwaną także więzią (wspólnotą) psychiczną lub duchową] małżonków definiuje się jako relację polegającą na ich wzajemnym, pozytywnym stosunku uczuciowym, szacunku, zaufaniu, szczerości, lojalności, wyrozumiałości, respektowaniu osobistych właściwości współmałżonka, uwzględnianiu jego osobistych potrzeb oraz gotowości do ustępstw i kompromisów ${ }^{42}$. Wydaje się, że więź emocjonalną między konkubentami należałoby rozumieć odpowiednio ${ }^{43}$. Więź ta uznawana jest przez przedstawicieli doktryny za ważny element składowy konkubinatu, o czym świadczyć może teza, że „istnienie między partnerami więzi psychicznej jest konstytutywnym i oczywistym warunkiem istnienia konkubinatu" ${ }^{\prime 4}$.

Więź fizyczna, podobnie jak wspomniana powyżej więź emocjonalna, uznawana jest, acz niejednomyślnie ${ }^{45}$, za istotny element konkubinatu pozwalający odróżnić go od innych wspólnot partnerskich ${ }^{46}$. Przyjmuje się jednak, że brak tej więzi nie wyklucza istnienia konkubinatu, jeżeli brak pożycia spowodowany jest czynnikami obiektywnymi, jak wiek partnerów, ich stan zdrowia, czy chwilowe rozłączenie, a istnieją podstawy do przypuszczeń, że partnerzy utrzymywaliby ze sobą pożycie fizyczne, gdyby było to obiektywnie możliwe ${ }^{47}$. Co więcej, wyrażony został pogląd, iż z istnieniem konkubinatu należy wiązać domniemanie faktyczne utrzymywania przez partnerów stosunków seksualnych ${ }^{48}$. Mimo akcentowanej doniosłości pożycia fizycznego jako cechy konkubinatu większość doktryny wskazuje, że związek oparty wyłącznie na więzi fizycznej konkubinatem nie jest ${ }^{49}$.

41 Por. ibidem, s. 33, 35; A. Szlęzak, Stosunki majątkowe między konkubentami. Zagadnienia wybrane, Poznań 1992, s. 16, jako element więzi gospodarczej uznaje współodpowiedzialność za ekonomiczne podstawy egzystencji grupy, co, jak się wydaje, zawiera się we wskazanym pojęciu obustronnych świadczeń.

M. Sychowicz, [w:] Kodeks rodzinny i opiekuńczy. Komentarz, red. K. Piasecki, Warszawa 2011, s. 147.

Oczywiście przy założeniu, że konkubinat należy definiować przynajmniej w jakimś zakresie w odniesieniu do małżeństwa.

B. Paul, op. cit., s. 10.

Kryterium to neguje np. F. Hartwich, Konkubinat.., passim; idem, Zwiazki partnerskie.., s. 76-77.

Zob. np. M. Nazar, Rozliczenia majątkowe..., s. 35-36; zob. też np. wskazany w przyp. 19 wyrok SN z 31 marca $1988 \mathrm{r}$.

M. Nazar, Rozliczenia majątkowe..., s. 35-36; tak też: B. Paul, op. cit., s. 10 oraz W. Ćwiek, Konkubinat, Warszawa 2002, s. 9.

B. Paul, op. cit., s. 10.

A. Zieliński, op. cit., s. 12; tak też, jak się wydaje, M. Nazar, Rozliczenia majątkowe..., s. 37, zob. też podaną tam literaturę. Wspomnieć w tym miejscu należy jednak, że zdaniem S. Szera, Konkubinat, „Studia Cywilistyczne” 1969, t. XIII-XIV, s. 355, konkubinat polegać może li tylko na utrzymywaniu stałych kontaktów seksualnych. 
Ze względu na znaczenie wspomnianych więzi w piśmiennictwie przedstawiono propozycję metody ustalania, czy dany związek posiada charakter konkubinatu, polegającej na przeprowadzeniu gradacji owych więzi. I tak, stwierdzenie braku więzi emocjonalnej między partnerami - z zastrzeżeniem sytuacji, gdy trwają oni w związku jedynie ze względu na konieczność wychowania dzieci - wystarczyłoby do odstąpienia od dalszego badania cech danego związku. Kolejnym etapem winno być stwierdzenie więzi fizycznej. Elementem, który przy istnieniu dwu poprzednio wskazanych więzi albo jedynie więzi psychicznej wskazywałby na istnienie konkubinatu, byłaby więź gospodarcza. Dopiero istnienie tych trzech więzi (ewentualnie dwóch - psychicznej i gospodarczej) statuowałoby istnienie konkubinatu. Szczególny status przyznaje się $\mathrm{w}$ myśl tego stanowiska więzi prokreacyjnej, rozumianej jako relacje między osobami wynikające z posiadania wspólnego potomstwa. Stwierdzenie jej uprawniałoby przyjęcie domniemania, usuwalnego rzecz jasna, że dany związek jest konkubinatem, gdyż przyjąć można, że osoby wychowujące razem potomstwo łączy więź emocjonalna oraz najprawdopodobniej fizyczna. Natomiast fakt, iż zadania wychowawcze wymagają jakiejś podstawy ekonomicznej, implikuje domniemanie istnienia więzi gospodarczej ${ }^{50}$. Warto $w$ tym miejscu wskazać, iż w orzecznictwie odrzucono tezę, zgodnie z którą sam fakt, iż z danego nieformalnego związku narodziło się dziecko, stanowi „najdobitniejszy dowód", iż ów związek jest konkubinatem ${ }^{51}$.

Jako ostatni element cechy konkubinatu, jaką jest istnienie wspólnoty życiowej, wskazane zostało wspólne zamieszkiwanie partnerów ${ }^{52}$. Jak podkreśla się w piśmiennictwie ${ }^{53}$, fakt ów bywa wyraźnie wskazywany jako istotna cecha konkubinatu - chociaż podnosi się niekiedy, iż przejściowe czy też pozorne rozłączenie partnerów nie stawia danego związku poza nawiasem kategorii konkubinatu, o ile między partnerami zachodzą jakieś więzi majątkowe o charakterze wspólnotowym ${ }^{54}$. Ustosunkowanie się do tej kwestii jest szczególnie istotne w obliczu zjawiska określanego jako "latowanie" (z ang. Living Apart Together, „LAT”, co można przetłumaczyć jako „życie osobno, ale razem”) definiowanego jako: „Szczególny rodzaj kohabitacji, trwała intymna relacja dwojga partnerów, którzy, niczym nie przymuszeni, decydują się na życie w dwóch różnych lokum. Nie muszą, ale chcą mieszkać osobno. Ich stan cywilny jest natomiast bez znaczenia" ${ }^{55}$. W przyszłości bowiem sądy mogą stanąć przed

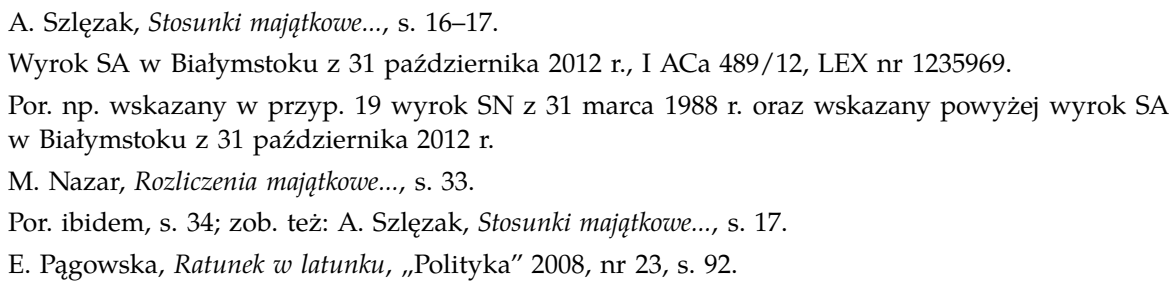


pytaniem, czy „latujących" partnerów - niebędących małżeństwem - uznać za konkubentów, a co za tym idzie, czy zastosować w ich przypadku np. reguły rozliczeń wypracowane dla konkubinatów, czy też nie.

Kolejną ze wskazywanych $\mathrm{w}$ doktrynie i orzecznictwie cech konkubinatu jest jego stabilność56. Omawiając tę cechę należy zacząć od stwierdzenia, że konkubinat będący jedynie zjawiskiem społecznym przestaje istnieć, gdy wygaśnie pożycie partnerów ${ }^{57}$. To zaś może nastąpić w dowolnej chwili, gdyż którykolwiek z partnerów może, bez spełnienia jakichkolwiek przesłanek i bez jakichkolwiek czynności formalnych, zakończyć związek w dowolnym momencie $^{58}$. Owa łatwość zerwania pożycia uznawana bywa za jeden z zasadniczych powodów tworzenia konkubinatów ${ }^{59}$. Tym też konkubinat różni się od małżeństwa, które jest związkiem trwałym, choć rozwiązywalnym. Małżeństwo istnieje dopóty, dopóki nie ustanie w płaszczyźnie prawnej (np. poprzez orzeczenie rozwodowe), nawet jeżeli między małżonkami nastąpił całkowity rozkład pożycia. Jak zauważa się $\mathrm{w}$ doktrynie, właśnie brak dowolności rozwiązania małżeństwa, a nawet, w pewnych przypadkach, niemożność jego sądownego rozwiązania statuuje przypisywaną mu zasadę trwałości ${ }^{60}$. Dlatego też należy zgodzić się $\mathrm{z}$ zaprezentowaną $\mathrm{w}$ piśmiennictwie tezą̧ ${ }^{61}$ iż $\mathrm{w}$ odniesieniu do konkubinatu należy używać określenia "stabilny", nie zaś "trwały”, jak proponuje część przedstawicieli nauki ${ }^{62}$. Ową stabilność konkubinatu określać należy przez intensywność dotychczasowych więzi, pamiętając jednak, iż w każdej chwili mogą one zostać zerwane ${ }^{63}$. Stabilność związku objawiać się może np. wzajemną troską partnerów, jawnością ich pożycia, czy też wspólnymi przedsięwzięciami, np. gospodarczymi ${ }^{64}$.

Następną z cech konkubinatu wskazywanych w literaturze jest jego heteroseksualny charakter ${ }^{65}$. Wynika to $\mathrm{z}$ faktu, iż konkubinat określa się $\mathrm{w}$ odniesieniu do instytucji małżeństwa, $\mathrm{w}$ jego zaś istotę wpisana jest odmienność płci. W związku z tym związkom homoseksualnym nie przyznaje się miana konkubinatów. Co więcej, nawet określenie „związki partnerskie” stosowane

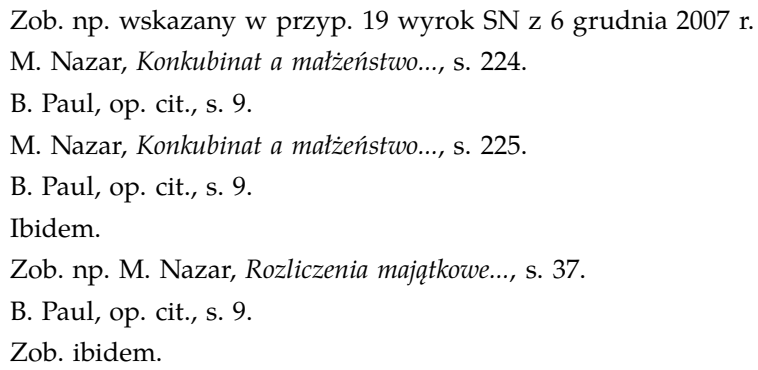

Zob. np. A. Szlęzak, Wybrane zagadnienia..., s. 27, przyp. 1; A. Wołoszko, Cywilnoprawne zagadnienia konkubinatu, „Przegląd Policyjny” 1999, nr 4, s. 194; S. Paździor, op. cit., s. 183; A. Zieliński, op. cit., s. 12; M. Nazar, Rozliczenia majątkowe..., s. 40. 
jest zwykle do oznaczania faktycznych związków heteroseksualnych ${ }^{66}$. Mając jednak na uwadze, że związki homoseksualne są faktem, który nie może być ignorowany na płaszczyźnie jurydycznej, w doktrynie podnosi się, iż przepisy wiążące skutki prawne $\mathrm{z}$ - mówiąc $\mathrm{w}$ uproszczeniu - faktycznym pożyciem winny być odnoszone także do związków osób tej samej płci, chyba że ograniczenie zakresu stosowania takich przepisów wynikałoby z potrzeby zapewnienia bezpieczeństwa, ochrony porządku publicznego, moralności publicznej itd. ${ }^{67} \mathrm{~W}$ takich przypadkach faktyczne pożycie winno być dookreślone jako małżeńskie ${ }^{68}$. W kwestii terminologii proponuje się np., by związki homoseksualne określać mianem „Związków osób tej samej płci”, ewentualnie jako "konkubinaty osób tej samej płci” tudzież „konkubinaty homoseksualne"69. W myśl tego stanowiska, jakkolwiek terminy zaproponowane jako ostatnie odbiegają od powszechnego ususu językowego, to jednak bezpośrednio i komunikatywnie nawiązują do terminu konkubinat (heteroseksualny), który to termin jest powszechnie używany oraz zrozumiały, a przez to mogą być operatywne $\mathrm{w}$ „rozstrzyganiu prawnych problemów zarówno na tle obowiązującego prawa krajowego, międzynarodowych zalecanych standardów prawnych (zwłaszcza Rady Europy), jak i w analizach prawnoporównawczych"70. Podkreśla się przy tym, iż nie ma przeszkód prawnych (brak definicji legalnej konkubinatu) ani językowych (usus podlega zmianom), uniemożliwiających: 1) stosowanie omawianego terminu do nieformalnych związków osób tej samej płci, 2) stosowanie omawianego terminu ze stosownym dookreśleniem ${ }^{71}$. W piśmiennictwie zaprezentowane zostało także stanowisko, w myśl którego należy zrezygnować $\mathrm{z}$ uznawania różnicy płci konkubentów za istotną cechę tego związku ${ }^{72}$. Także $\mathrm{w}$ orzecznictwie zaprezentowano pogląd, iż różnica płci nie jest elementem koniecznym dla uznania danego związku za konkubinat ${ }^{73}$. Pogląd ten jest jednak odosobniony. Warto w tym miejscu wskazać, iż stanowisko to zostało poddane krytyce przez SN, który rozpatrywał skargę kasacyjną wniesioną od wspomnianego orzeczenia ${ }^{74}$. Sąd ten podniósł, iż wobec braku ustawowej regulacji konkubinatu $\mathrm{w}$ doktrynie i orzecznictwie wypracowane zostały kryteria pozwalające zaklasyfikować dany związek jako konkubinat, a jednym $z$ nich jest odmienność płci osób go tworzących. Ponadto, zdaniem

\footnotetext{
Zob. M. Nazar, Konkubinat, [w:] System..., s. 910 oraz wskazaną tam literaturę.

Ibidem, s. 911.

Ibidem.

M. Nazar, Konkubinat a małżeństwo..., s. 222.

Ibidem, s. 222-223.

M. Nazar, [w:] Prawo rodzinne, J. Ignatowicz, M. Nazar, Warszawa 2012, s. 105.

B. Paul, op. cit., s. 10; zob. też: F. Hartwich, Związi partnerskie.., s. 79.

Zob. wskazany w przyp. 14 wyrok SA w Białymstoku z 23 lutego 2007 r.

Zob. wspomniany w przyp. 19 wyrok SN z 6 grudnia $2007 \mathrm{r}$.
} 
sądu, przeciwko objęciu omawianym terminem związków homoseksualnych przemawia ugruntowana tradycja, także językowa, jak również „ujmowanie cech wspólnot konkubenckich w nawiązaniu do modelu wspólnot małżeńskich, a więc dotyczących wyłącznie związków osób różnej płci" - co jednak należałoby zaliczyć jako element wspomnianej ugruntowanej tradycji, nie zaś samodzielny argument. Dodatkowo SN wskazał, iż rozróżnienie pomiędzy nieformalnymi związkami hetero- i homoseksualnymi utrzymuje się $w$ większości krajów Unii Europejskiej, jak również uwzględniane jest w orzecznictwie Trybunału Sprawiedliwości Unii Europejskieji ${ }^{75}$. Warto na zakończenie tego fragmentu rozważań zauważyć, iż skutkiem eliminacji kryterium różnicy płci w omawianej materii byłoby teoretycznie automatyczne stosowanie do związków homoseksualnych reguł wypracowanych w stosunku do tradycyjnie pojmowanego konkubinatu. $W$ tym miejscu pojawia się pytanie, jak w takim przypadku stosować przepisy dookreślające faktyczne pożycie jako "małżeńskie"? Jedynym rozwiązaniem w przypadku utrzymania tego typu przepisów byłoby mimo wszystko przyjęcie faktycznego podziału konkubinatów na homo- i heteroseksualne. Przy czym, z uwagi na niemal jednolite stanowisko doktryny i orzecznictwa, uznające odmienność płci partnerów za istotny element omawianego konkubinatu ${ }^{76}$, bardziej prawdopodobne wydaje się przyjęcie nowego terminu na określenie nieformalnego związku osób tej samej płci.

Analizując wskazywane w doktrynie cechy konkubinatu, odnieść się należy także do kwestii notoryjności, monogamiczności oraz instrumentalności i niesprzeczności z prawem (nawet potencjalnej) tego związku.

$\mathrm{W}$ doktrynie wskazuje się, iż konkubinat z natury rzeczy jest notoryjny, jako że wyraża się we wspólnym zamieszkiwaniu partnerów, prowadzeniu wspólnego gospodarstwa domowego, utrzymywaniu zewnętrznie postrzegalnych osobistych więzi partnerskich - nie można wskazać jakiegoś autonomicznego elementu konkubinatu, który samoistnie czyniłby go notoryjnym ${ }^{77}$. W niektórych definicjach omawianego pojęcia wskazuje się jako jedną z jego cech jawność wobec osób trzecich ${ }^{78}$. Jak jednak wskazuje część przedstawicieli doktryny, należy odróżnić jawność konkubinatu jako takiego od jawności samej heteroseksualnej wspólnoty, która może być oznaką tak związku nieformalnego, jak i małżeństwa ${ }^{79}$. Niestety, autor owej tezy nie rozwija tego wątku, zaś

75 W tej mierze wskazano m.in. wyrok Trybunału Sprawiedliwości z 17 lutego 1998 r., Grant v. South-West Trains Ltd, C-249/96, LEX nr 111552.

76 Tak K. Pietrzykowski, [w:] Kodeks rodzinny i opiekuńczy. Komentarz, red. K. Pietrzykowski, Warszawa 2012, s. 104

77 M. Nazar, Rozliczenia majattkowe..., s. 41-42.

78 Zob. np. A. Wołoszko, op. cit., s. 194.

79 Por. M. Nazar, Rozliczenia majatkowe..., s. 42. 
inni przedstawiciele doktryny pomijają ten aspekt. Nie można więc określić, czy notoryjność w świetle doktryny jest istotną cechą konkubinatu, a jeżeli tak, to w którym znaczeniu - jawności związku nieformalnego jako takiego, czy też jawności samej wspólnoty ${ }^{80}$.

Kolejnym aspektem konkubinatu poruszanym w doktrynie jest jego monogamiczność. W kwestii tej, co jest regułą, doktryna jest podzielona. W większości przypadków określenia konkubinatu nie poruszają tego aspektu, co wiąże się zapewne z przyjęciem stanowiska, iż konkubinat definiuje się przez odniesienie do małżeństwa. $\mathrm{W}$ takim zaś przypadku wymóg monogamicznego charakteru związku jawi się jako oczywisty. Wśród autorów poruszających ten wątek wyróżnić można, siłą rzeczy, dwa stanowiska. Część doktryny sytuuje związki niemonogamiczne poza zakresem tego pojęcia ${ }^{81}$. Część zaś opowiada się za tym, by nie ograniczać zakresu pojęcia konkubinatu do związków monogamicznych ${ }^{82}$. Stanowisko to jest przy tym zasadniczo formułowane $\mathrm{w}$ odniesieniu do sytuacji, w której jeden z partnerów (albo oboje) pozostaje $\mathrm{W}$ związku małżeńskim ${ }^{83}$. W takim też kontekście pojawiło się $\mathrm{w}$ orzecznictwie, gdzie sąd określił mianem konkubinatu wspólnotę życiową, której jedna ze stron pozostawała $\mathrm{w}$ związku małżeńskim ${ }^{84}$. Powstaje jednak pytanie, czy takie samo stanowisko zajęto by $\mathrm{w}$ przypadku, gdyby osoby tworzące dany związek nieformalny pozostawały jednocześnie $\mathrm{w}$ analogicznym związku z innymi partnerami, tudzież gdyby daną wspólnotę życiową tworzyło kilka osób - na wzór znanego niektórym ustawodawstwom małżeństwa poligamicznego? Wydaje się, że w odniesieniu do tego problemu zarysowałyby się dwa stanowiska - pro i contra. Przy czym najprawdopodobniej przeważałoby to, zgodnie z którym związek taki nie jest konkubinatem. Teza ta jest bowiem logicznym następstwem przyjęcia stanowiska, iż omawiany związek różni się od małżeństwa $\mathrm{w}$ zasadzie tylko brakiem formalizacji ${ }^{85}$ (takie zaś, jak się wydaje, jest dominujące stanowisko doktryny i orzecznictwa). Skoro zaś konkubinat jest małżeństwem de facto, wykluczona zostaje ex definitione jego potencjalna nawet poligamiczność.

80 Przepisy stosowane w odniesieniu do konkubinatu nie wymagają jego notoryjności, jednak jawność taka może mieć znaczenie w sferze stosunków prawnych konkubentów z osobami trzecimi, a także ułatwiać dokonywanie rozliczeń między partnerami po ustaniu związku, czy też stosowanie do nich przepisów uwzględniających istnienie - w uproszczeniu - (faktycznego) pożycia między nimi, zob. M. Nazar, Konkubinat a małżeństwo..., s. 225-226; idem, Rozliczenia majątkowe..., s. 42 oraz S. Szer, op. cit., s. 360.

Zob. np. M. Nazar, Rozliczenia majątkowe..., s. 41 oraz wskazaną tam literaturę; F. Hartwich, Związki partnerskie..., s. 78-79.

Zob. np. M. Nazar, Konkubinat a matżeństwo..., s. 227; A. Szlęzak, Stosunki majątkowe..., s. 97.

Zob. wyrok SN z 26 października 2000 r., II CKN 956/99, LEX nr 45570.

Tak np. A. Zieliński, op. cit., s. 12. 
Trzecią ze wskazanych uprzednio cech konkubinatu jest jego nieinstrumentalność. Oznacza to, że za konkubinat uznać należy związek, w którym partnerzy utrzymują pożycie dla niego samego, choćby tę formę pożycia wybrali po to, by uniknąć utraty określonych korzyści, np. alimentów od byłego małżonka ${ }^{86}$, którą to stratę wywołałoby niechybnie zawarcie związku małżeńskiego ${ }^{87}$. Nie będzie natomiast konkubinatem wspólnota, w której wspólne pożycie będzie instrumentalnie pozorowane $w$ celu osiągnięcia określonych korzyści, np. wstąpienia $\mathrm{w}$ najem mieszkania $\mathrm{w}$ razie śmierci jego najemcy ${ }^{88}$ - co oznacza, że para rozpadłaby się, gdyby odpadła owa korzyśśc 89 .

Ostatnią ze wskazanych cech konkubinatu jest niesprzeczność (nawet potencjalna) owej wspólnoty, samej w sobie, z prawem. Kryterium to zaproponowano w związku z odrzuceniem stanowiska, zgodnie z którym konkubinat winien być określany poprzez analogię do małżeństwa ${ }^{90}$. Dzięki temu możliwe stało się zaliczenie do zakresu pojęcia "konkubinat” związków homoseksualnych. Skutkiem tego, jak wskazuje się w piśmiennictwie, mogłyby się jednak pojawić zarzuty, że nie ma już podstaw do odmowy podobnej ochrony prawnej np. związkom kazirodczym ${ }^{91}$. Wprowadzenie tego kryterium pozwala usunąć ten problem, gdyż homoseksualizm jako taki jest irrelewantny prawnie, natomiast np. wspomniane kazirodztwo jest penalizowane ${ }^{92}$. W nieco szerszym ujęciu, o zgodności konkubinatu z prawem mówi się nie tylko w kontekście potencjalnego utrzymywania przez partnerów relacji seksualnych, ale także zawieranych przez nich porozumień, które nie mogą ograniczać prawa do samookreślania każdego $\mathrm{z}$ nich ${ }^{93}$.

Jak zatem definiowane jest $\mathrm{w}$ doktrynie i orzecznictwie pojęcie konkubinatu? Niejednolicie. Tytułem przykładu wskazać można następujące propozycje: 1) niesformalizowana przez zawarcie małżeństwa osobisto-majątkowa wspólnota życiowa partnerów, utworzona przez nich z zamiarem trwałego jej utrzymania, bez względu na motywy odrzucenia instytucji małżeństwa ${ }^{94}$;

86 łego) małżonka osoby pozostającej w związku nieformalnym zob. szerzej np. A. Szlęzak, Wybrane zagadnienia..., s. 29-33.

87 nie do tego kryterium zaproponowanego przez A. Szlęzaka, Stosunki majątkowe..., s. 15-16; zob. M. Nazar, Rozliczenia majątkowe..., s. 42-43.

M. Nazar, Konkubinat a małżeństwo..., s. 226.

A. Szlęzak, Stosunki majątkowe..., s. 16. Zaznaczyć jednak należy, iż zdaniem tego autora instrumentalnie pojmowany związek może być uznany za konkubinat, jeżeli partnerzy przebywają razem wyłącznie ze względu na wychowywanie wspólnych dzieci, zob. ibidem, s. 15.

B. Paul, op. cit., s. 10; por. też: F. Hartwich, Związki partnerskie..., s. 80-81.

B. Paul, op. cit., s. 10.

Ibidem.

Zob. F. Hartwich, Zwiazki partnerskie..., s. 80-82.

M. Nazar, Rozliczenia majątkowe..., s. 43. 
2) związek faktyczny dwojga partnerów odmiennej płci, względnie trwały, jawny wobec osób trzecich, wykazujący podobieństwo do pożycia małżeńskiego, zachodzącego w płaszczyźnie trzech więzi: duchowej, fizycznej i materialnej ${ }^{95}$; 3) związek kobiety i mężczyzny funkcjonalnie zbliżony do małżeństwa, lecz pozbawiony elementu formalnego, tzn. powstały bez aktu urzędowego, jakim jest złożenie oświadczeń woli o wstąpieniu w związek małżeński przed urzędnikiem USC (pamiętać trzeba, że definicja ta została sformułowana przed wprowadzeniem przepisów umożliwiających zawarcie małżeństwa wyznaniowego ze skutkami przewidzianymi $\mathrm{w}$ prawie polskim) ${ }^{96}$; 4) stabilna wspólnota faktyczna, sama w sobie nawet potencjalnie niesprzeczna z prawem, istniejąca pomiędzy dwiema osobami różnej lub tej samej płci, połączonymi więzią psychiczną, fizyczną i gospodarczą ${ }^{97}$. W orzecznictwie zaś konkubinat określany bywa jako: 1) stabilna, faktyczna wspólnota osobisto-majątkowa dwojga osób, bez względu na ich płeć98; 2) prawnie nieuregulowana, trwała wspólnota życiowa mężczyzny i kobiety. W związku z czym wskazuje się, że konkubinat to: a) związek mężczyzny i kobiety, b) związek trwały, c) charakteryzujący się pożyciem analogicznym jak w małżeństwie, d) istniejący przy braku zdarzenia prawnego regulującego ten związek. Zewnętrznym przejawem wymienionej trwałości i pożycia są: współżycie fizyczne, wspólne zamieszkiwanie i wspólne prowadzenie gospodarstwa domowego ${ }^{99}$. Jak widać, nie stracił na aktualności pogląd, iż, odnośnie do pojęcia konkubinatu, poza sporem jest przeważnie tylko to, że chodzi o trwałe pożycie kobiety i mężczyzny niepołączonych węzłem małżeńskim ${ }^{100}$. Pozostałe cechy konkubinatu stanowią już w doktrynie (a także - choć w mniejszym stopniu - orzecznictwie ${ }^{101}$ ) materię par excellence sporną.

Związki nieformalne tworzą bardzo niejednorodną grupę. Zaliczyć do nich można np. wspólnoty osób mieszkających ze względów merkantylnych w jednym lokalu, „klasyczne” konkubinaty i ich homoseksualne odpowiedniki,

\footnotetext{
95 A. Wołoszko, op. cit., s. 194.

96 A. Szlęzak, Wybrane zagadnienia..., s. 27, przyp. 1.

97 B. Paul, op. cit., s. 10-11.

101 Wynika to z faktu, iż w judykatach Sądu Najwyższego związek ten określany jest jako trwała wspólnota faktyczna kobiety i mężczyzny, którą cechują relacje analogiczne do tych występujących w prawidłowym małżeństwie, w szczególności więź psychiczna, fizyczna i ekonomiczna tak: B. Paul, op. cit., s. 8. Wziąwszy pod uwagę autorytet Sądu Najwyższego oraz fakt, iż jego orzeczenia mają charakter precedensów de facto (szerzej w tym zakresie patrz np. L. Morawski, Główne problemy wspótczesnej filozofii prawa. Prawo w toku przemian, Warszawa 2003, s. 252 i nast.), uprawniona jest teza, iż sądy będą definiować konkubinat zgodnie ze stanowiskiem SN, a orzeczenia takie jak wspominany kilkakrotnie wyrok SA w Białymstoku z 23 lutego 2007 r., będą należeć do rzadkości.
} 
związki oparte wyłącznie na więzi fizycznej i wiele innych. Dlatego też w piśmiennictwie postuluje się m.in. przyjęcie określenia znaczeniowo szerszego niż konkubinat, a zarazem posiadającego neutralny wydźwięk, np. związek partnerski ${ }^{102}$. Podkreśla się przy tym, że $\mathrm{z}$ uwagi na ową różnorodność nie jest zasadne podejmowanie próby zdefiniowania związku partnerskiego, czy nawet węziej rozumianego konkubinatu. Wynikać to ma z faktu, iż określenie koniecznych a zarazem wyłącznych przesłanek takich związków (poza przesłankami ogólnymi, tj. istnieniem wspólnoty życiowej partnerów, braku zawarcia przez nich związku małżeńskiego oraz zgodności związku z prawem), nie jest możliwe ani wskazane ${ }^{103}$. $Z$ pierwszą tezą wypada się częściowo zgodzić. Istotnie zasadne jest przyjęcie ogólnego terminu określającego związki nieformalne o pewnych zasadniczych cechach wspólnych, choćby ze względów klasyfikacyjnych. Niekoniecznie jednak musi być to termin „związek partnerski". Wskazuje się bowiem, nie bez racji, iż jest on niedookreślony znaczeniowo. Związkiem partnerskim $\mathrm{w}$ obecnych warunkach jest bowiem $\mathrm{z}$ założenia także małżeństwo, $\mathrm{w}$ ramach którego istnieje pełne uprawnienie, a małżonkowie są dla siebie równorzędnymi partnerami ${ }^{104}$. Niezależnie jednak od tego, jaki ostatecznie termin uznano by za prawidłowy, zgodzić się należy, iż powinien być on określony możliwie ogólnie. Pamiętać przy tym trzeba, iż będzie to dopiero pierwszy krok. Siłą rzeczy bowiem zaistnieje potrzeba utworzenia podobnie ogólnego terminu na określenie nieformalnych związków niespełniających owych cech konstytutywnych. Ponadto konieczne będzie zdefiniowanie poszczególnych typów związków w ramach danego zbioru. Wynika to z faktu, iż nie każdy nieformalny związek zasługuje na ochronę prawną ${ }^{105}$. Co więcej, ustawodawca niekiedy wyraźnie zawęża ową ochronę do określonego typu związku nieformalnego np. poprzez wskazanie, iż dotyczy to osoby pozostającej $\mathrm{w}$ faktycznym małżeńskim pożyciu $\mathrm{z}$ określoną $\mathrm{w}$ danym przepisie osobą. W realiach polskich termin „konkubinat” niewątpliwie będzie występować $w$ dyskursie prawniczym dotyczącym tejże materii. Stąd zdefiniowanie go wydaje się być jak najbardziej celowe. Przy czym, z uwagi na trudności $\mathrm{w}$ wytyczeniu ostrych granic konkubinatu, wydaje się, iż winna to być definicja typologiczna (oparta na schemacie bardziej - mniej nie zaś albo - albo) $)^{106}$.

102 Zob. np. F. Hartwich, Związki partnerskie..., s. 86.

103 Ibidem, s. 82-83.

104 Zob. T. Smyczyński, Małżeństwo - konkubinat - związek partnerski, [w:] Związi partnerskie. Debata na temat projektowanych zmian prawnych, red. M. Andrzejewski, Torun 2013, s. 73.

105 Zob. A. Szlęzak, Stosunki majątkowe..., s. 12; B. Paul, Francuskie przepisy o konkubinacie, „Kwartalnik Prawa Prywatnego" 2002, z. 3, s. 758.

106 Por. M. Romanowski, Podział praw podmiotowych na majątkowe i niemajątkowe, "Państwo i Prawo” 2006, z. 3, s. 26-28. Szerzej nt. typologii patrz np. Logika dla prawników. Słownik encyklopedyczny, red. A. Malinowski, Warszawa 2012, s. 227; Z. Ziembiński, Logika praktyczna, Warszawa 2009, s. 61-62. 
W piśmiennictwie zwrócono uwagę, iż nie ma powodu, by związki nieformalne oceniać według zasad ustalonych dla małżeństw, jako że te pierwsze "oderwały się" od tych drugich ${ }^{107}$, a dzisiejsi konkubenci wcale nie chcą żyć jak małżonkowie, w przeciwnym razie zawarliby po prostu związek małżeński, jako że przeszkody prawne tudzież materialne tylko w wyjątkowych sytuacjach stałyby temu na przeszkodzie ${ }^{108}$. Z tezą tą wypada się częściowo zgodzić. Niewątpliwie sytuacja, gdy dane osoby mogą się pobrać, a pomimo to decydują się na utworzenie związku nieformalnego, wskazuje na to, iż nie chcą one funkcjonować $\mathrm{w}$ ramach określonych dla tejże instytucji. Podobnie gdy ustanowienie takiego związku wynika z faktu, iż dana relacja nie spełnia warunków umożliwiających nadanie jej statusu małżeństwa. Osoby decydujące się na taką formę „bycia razem” niewątpliwie nie chcą żyć jak w małżeństwie, nie oznacza to jednak, iż nie chcą żyć, w jakimś zakresie, jak małżonkowie. Chociaż z uwagi na różnorodność form związków nieformalnych da się zapewne wskazać takie, w stosunku do których przytoczony pogląd znajduje pełne zastosowanie. Mówiąc jednak o konkubinacie odnosimy się do specyficznego typu związku nieformalnego, którego wyróżnienie wydaje się zasadne w świetle terminologii ustawowej. Warto zauważyć, iż w odniesieniu do wspomnianych powyżej osób, które "mogą ale nie chcą” zawrzeć związku małżeńskiego wskazać można kilka przyczyn kohabitacji. W piśmiennictwie wskazuje się, że stanowić ona może wstęp do małżeństwa, może być traktowana jako rodzaj małżeństwa albo alternatywa dla życia małżeńskiego ${ }^{109}$. Część osób funkcjonujących $\mathrm{w}$ takich nieformalnych związkach podkreśla, że żyją jak małżonkowie, jedyną różnicą jest brak formalizacji związku ${ }^{110}$. W przypadku osób traktujących kohabitację jako alternatywę dla małżeństwa wskazuje się, iż głównymi powodami sięgnięcia po tę formę „bycia razem" są: negatywne nastawienie do małżeństwa postrzeganego jako instytucja patriarchalna, tudzież rozczarowanie co do niego z uwagi na jego nieefektywność, czy wręcz niebezpieczeństwo, jakie ze sobą niesie, np. ekonomiczne i psychologiczne koszty rozwodu, jako jedynej formy jego zakończenia. W tej grupie osób jako czynnik motywujący do utworzenia nieformalnego związku wskazuje się niekiedy także brak rygoryzmu i formalizmu $\mathrm{w}$ zakresie nawiązania i zakończenia związku, ty-

107 F. Hartwich, Związki partnerskie..., s. 77.

108 Idem, Konkubinat..., s. 65.

109 Zob. A. Barlow, S. Duncan, G. James, A. Park, Cohabitation, Marriage and the Law. Social Change and Legal Reform in the 21st Century, Oxford - Portland 2005, s. 65. W literaturze spotkać można także bardziej rozbudowane klasyfikacje; przykładowo, w ramach jednej z nich wskazuje się, iż kohabitacja może: a) poprzedzać małżeństwo i stanowić okres przedłużonego „chodzenia ze sobą", b) poprzedzać małżeństwo i stanowić przygotowanie do niego, c) stanowić alternatywną formę małżeństwa, zwłaszcza dla osób, które nie zamierzają się pobrać, d) stanowić formę niezamężnego życia, wyrastającą z ideologii niezależności, zob. K. Slany, Alternatywne formy życia matżeńsko-rodzinnego w ponowoczesnym świecie, Kraków 2002, s. 135-136.

110 Szerzej w tym zakresie patrz: A. Barlow, S. Duncan, G. James, A. Park, op. cit., s. 67-72. 
powego dla małżeństwa ${ }^{111}$. Ponadto, w literaturze wskazuje się, że osoby, dla których kohabitacja stanowi alternatywną, ale trwałą formę współżycia mają do spełnienia określone zadania, podobnie jak w małżeństwie ${ }^{112}$. Tak więc nie od rzeczy wydaje się zdefiniowanie konkubinatu w odniesieniu do małżeństwa. Wydaje się nawet, że zabieg ten można przeprowadzić także w stosunku do innych związków nieformalnych, jako że rozumienie pewnych pojęć, np. pozostawania we wspólnocie życiowej wypracowane na gruncie instytucji małżeństwa, stanowi najlepszy „punkt zaczepienia”, jakim dysponujemy. Pamiętać jednak należy, by nie utożsamiać tych instytucji. Nie wolno tracić z pola widzenia specyfiki związków nieformalnych, w tym konkubinatu. Traktowanie tego typu wspólnot jako quasi-małżeńskich nie jest samo w sobie złe. Konieczne jest jednak położenie większego nacisku na człon quasi niż na człon „małżeństwo".

W polskich realiach konkubinat postrzegany jest, jak się wydaje, jako „modelowy" związek nieformalny. Możliwe jest więc, że będzie on punktem odniesienia przy ocenie innych już istniejących, jak i mogących pojawić się w przyszłości form „bycia razem”. Dlatego też zasadne jest sformułowanie typologicznej definicji konkubinatu. Jest to niewątpliwie zadanie trudne. W płaszczyźnie praktycznej ów problem znaczeniowy rozwiązać może jedynie ustawodawca, wprowadzając stosowną definicję legalną. Na marginesie zauważyć warto, iż jego ingerencja tak czy inaczej wydaje się nie od rzeczy. Zasadne bowiem jest uporządkowanie terminologii ustawowej odnoszącej się do osób tworzących nieformalne wspólnoty. W obecnym stanie rzeczy definicja konkubinatu musi „wykuć się" w toku dyskursu doktrynalno-orzeczniczego. Dlatego też warto przedstawić, w oparciu o przytoczone powyżej stanowiska przedstawicieli nauki oraz sądów polskich, kilka uwag, które mogą w jakimś stopniu wzboga-

111 Szerzej w tym zakresie patrz: ibidem, s. 72-74.

112 K. Slany, op. cit., s. 137. Wśród owych zadań wymienia się m.in.: 1) utworzenie wspólnego miejsca zamieszkania, które można nazwać domem; 2) utworzenie wspólnego, wzajemnie satysfakcjonującego rodzinnego systemu ekonomicznego, uwzględniającego zarabianie i wydawanie pieniędzy przy podkreśleniu pracy kobiet, wspierającej materialnie rodzinę; dostosowanie systemu do istniejących zasobów finansowych; 3) wynegocjowanie podziału ról według opcji tradycyjnej bądź egalitarnej; przy aktywności zawodowej kobiety korzystny jest elastyczny podział, oparty na osobistych kompetencjach i preferencjach; 4) utworzenie wzajemnie satysfakcjonującego pożycia seksualnego przy wynegocjowaniu sposobów regulacji poczęć; 5) utworzenie intelektualnej i komunikacyjnej wspólnoty, co pomoże rozwiązywać konflikty; 6) utworzenie efektywnych relacji z krewnymi (w system uwikłane są trzy rodziny - własna i dwie rodziny orientacji: jego i jej); 7) utworzenie efektywnych relacji z kręgami przyjacielskimi, koleżeńskimi, sąsiedzkimi, organizacjami, instytucjami itd., które wciągają podmioty w życie społeczne; 8) planowanie rodziny, przyjścia na świat dziecka; większość ludzi deklaruje chęć posiadania dzieci; 9) utworzenie wspólnej filozofii życia jako para (wspólne przekonania i wartości); wypracowanie podstaw podejmowania strategicznych decyzji życiowych; negocjowanie odgrywanych ról, oparte bardziej na wzajemnych pozytywnych interakcjach niż na normatywnych, przypisanych wymogach; adaptowalność do zmian; 10) uznanie sfery seksualnej nie tylko za siłę reprodukcyjną, ale i wiążącą, i spajającą partnerów, zob. ibidem, s. 137-138. 
cić ów dyskurs i przyczynić się tym samym do osiągnięcia wspomnianego rezultatu.

Poza sporem pozostaje wymóg braku uznanej przez prawo więzi małżeńskiej, ten więc element można uznać za „pewnik” w definicji konkubinatu. Bardziej problematyczna jest kwestia odmienności płci partnerów albo jej braku. Wydaje się, że z uwagi na ugruntowaną tradycję (sięgającą czasów rzymskich) mało prawdopodobne jest, by związki jednopłciowe zostały uznane za konkubinaty. Nie oznacza to jednak, że zostaną pozbawione jakiegokolwiek znaczenia prawnego, o ile brzmienie określonego przepisu nie zawęzi możliwości jego stosowania do związków heteroseksualnych. Konieczne jednak będzie stworzenie nowego terminu na ich określenie, chyba że zwrot konkubinat zostanie zastąpiony innym pojęciem (np. występującym w piśmiennictwie francuskojęzycznym sformułowaniem „wolny związek” - l'union libre), co pozwoli na ujęcie w ramach jednej kategorii związków tak jedno-, jak i dwupłciowych, $\mathrm{o}$ ile nie będą się one różnić $\mathrm{w}$ pozostałym zakresie ${ }^{113}$.

Kolejnym elementem, który, jak wydaje się, powinien znaleźć się w przedmiotowej definicji, jest istnienie wspólnoty życiowej partnerów, statuowanej przez istnienie więzi psychicznej, fizycznej oraz gospodarczej. Więź emocjonalną należałoby chyba rozumieć analogicznie jak w przypadku małżonków, acz z wyłączeniem obowiązku lojalności w zakresie, w jakim obejmuje on wierność. Więź fizyczna w tym kontekście stanowi element odróżniający konkubinat od innych nieformalnych związków, jej uwzględnienie wydaje się zasadne także $w$ świetle zaprezentowanego powyżej podejścia osób kohabitującyh do ich związku114. Przy czym zgodzić się należy, iż brak owej więzi nie wyklucza istnienia konkubinatu, jeśli spowodowany jest on czynnikami obiektywnymi i można zasadnie przypuszczać, że w braku owych przeszkód partnerzy utrzymywaliby relacje seksualne. W przypadku więzi gospodarczej zasadne jest, jak sądzę, przyjęcie, iż przejawiać się ona powinna $\mathrm{w}$ obustronnym ponoszeniu świadczeń (osobistych lub majątkowych) służących zaspokojeniu bieżących lub długofalowych celów danego związku (co należałoby interpretować szeroko). Wspólnemu zamieszkiwaniu partnerów nie należy przypisywać charakteru konstytutywnego w zakresie definicji konkubinatu. Dziwne bowiem byłoby np. pozostawienie poza zakresem tegoż pojęcia pary połączonej więzią psychiczną i fizyczną, prowadzącej wspólne przed-

113 Na marginesie warto zwrócić uwagę na fakt, iż w piśmiennictwie pod pojęciem kohabitacji (które wydawać by się mogło „neutralne” w zakresie orientacji seksualnej partnerów) rozumie się związek heteroseksualny, zob. np. P. R. Newcomb, Cohabitation, [w:] International Encyclopedia of the Social Sciences, red. W. A. Darity Jr, t. 2: Cohabitation - Ethics in Experimentation, Detroit 2008, s. 1; K. Slany, op. cit., s. 135.

114 Warto przy tym wskazać, iż w piśmiennictwie francuskim podnosi się, iż wymiar seksualny ma znaczenie fundamentalne w przypadku tego typu związków nieformalnych: „nie ma białych konkubinatów", P. Malaurie, H. Fulchiron, La Famille, Paris 2011, s. 160. 
sięwzięcia gospodarcze, mieszkającej jednak w odrębnych lokalach. Konkubinat winien cechować się także stabilnością, którą należałoby oceniać a casu ad casum - poprzez intensywność więzi łączących partnerów, pamiętając jednak, że w każdej chwili mogą one zostać zerwane, jako że do konstytutywnych cech omawianego związku należy łatwość jego zakończenia. Przejawem owej stabilności mogłoby być, jak słusznie podniesiono w piśmiennictwie, prowadzenie przez konkubentów wspólnych przedsięwzięć gospodarczych, czy też jawność ich pożycia. Przy czym należy opowiedzieć się przeciwko uznaniu notoryjności za cechę konstytutywną omawianego związku nieformalnego. Fakt, iż osoby postronne nie wiedzą o tym, że dani ludzie tworzą wspólnotę o charakterze konkubenckim, czy nawet parę (pamiętajmy bowiem o wyróżnieniu w piśmiennictwie dwóch rodzajów notoryjności), nie powinien mieć bowiem wpływu na status związku, o ile spełnia on pozostałe przesłanki. Przy czym trudno wyobrazić sobie sytuację, w której fakt, iż dane osoby "są ze sobą" nie był nikomu znany. Zasadne jest z kolei przyjęcie, iż dany związek aby mógł zostać określony mianem konkubinatu, winien charakteryzować się nieinstrumentalnością (tj. utrzymywany winien być dla niego samego, nawet jeżeli wiąże się to z jakimiś dodatkowymi korzyściami, nie zaś jedynie ze względu na owe korzyści), a także niesprzeczny (nawet potencjalnie) z prawem. Dzięki temu unika się bowiem sytuacji, w której powstają "fikcyjne związki" nakierowane jedynie na uzyskanie określonych korzyści, a także możliwości usankcjonowania w pewnym zakresie związków godzących w podstawy funkcjonowania społeczeństwa (i dlatego penalizowanych).

Kończąc niniejsze rozważania, odnieść się należy do ostatniej ze wskazywanych $\mathrm{w}$ doktrynie cech konkubinatu, a mianowicie monogamiczności. Otóż ograniczanie zakresu omawianego pojęcia do związków dwuosobowych nie wydaje się zasadne ${ }^{115}$. Pamiętać należy, iż konkubinat pierwotnie nie był związkiem monogamicznym (możliwe było pozostawanie w konkubinacie pomimo małżeństwa $\mathrm{z}$ inną osobą, mężczyzna mógł mieć wiele konkubin), jako taki zaczął być postrzegany dopiero z czasem, gdy zbliżono go do instytucji małżeństwa i traktowano jako jego „nierówną” formę ${ }^{116}$. Zatem przypisywanie mu monogamicznego charakteru można uznać za przejaw zbytniego akcentowania podobieństwa tego rodzaju związku do małżeństwa, przy pomijaniu istotnych różnic. W sytuacji, w której dana osoba pozostaje $\mathrm{w}$ kilku związkach nieformalnych ewentualnie tworzy związek poligamiczny poza wątpli-

115 Takie stanowisko prezentowane jest także na gruncie ustawodawstwa francuskiego, zob. np. P. Malaurie, H. Fulchiron, op. cit., s. 161. Jednakowoż wyrażany jest także pogląd przeciwny, tak w orzecznictwie (zob. ibidem), jak i doktrynie, por. np. X. Labbée, Le droit commun du couple, Villeneuve d'Ascq 2012, s. 56, 61.

116 W. Litewski, Słownik encyklopedyczny prawa rzymskiego, Kraków 1998, s. 50. 
wościami natury moralnej (czy dodatkowymi wątpliwościami natury moralnej, jako że konkubinat monogamiczny także postrzegany jest przez część osób negatywnie), nie ma powodów, by pozostawić tego typu związek poza kategorią konkubinatu ${ }^{117}$. Skoro jednak uznaje się i akceptuje (w jakimś zakresie) istnienie konkubinatu monogamicznego, a z istoty tego typu związku wynika, iż jest on „luźno" powiązany z małżeństwem, także niechęć do związków poligamicznych nie powinna skutkować zawężeniem omawianego pojęcia do wspólnot dwuosobowych. Na marginesie zauważyć wypada, iż takie związki w europejskich realiach kulturowych będą występować raczej rzadko ${ }^{118}$. W konsekwencji wydaje się, że w ujęciu typologicznym konkubinat należałoby określić jako heteroseksualny, stabilny, jawny (albo nie) związek dwojga (lub większej liczby) osób niepołączonych więzią małżeńską, mieszkających razem (albo osobno), charakteryzujący się istnieniem wspólnoty życiowej partnerów (którą konstytuują więzi emocjonalna, fizyczna oraz szeroko rozumiana więź gospodarcza), nieinstrumentalnością oraz niesprzecznością (nawet potencjalną) $\mathrm{z}$ prawem.

Zmiany zachodzące $\mathrm{w}$ społeczeństwie skutkują m.in. tworzeniem się nietradycyjnych wspólnot, które funkcjonują w danej przestrzeni prawnej. Części tego typu związków udzielana jest $\mathrm{w}$ określonym zakresie ochrona prawna, nie można też wykluczyć, że osoby tworzące takie wspólnoty będą dążyć do jej poszerzenia czy też uzyskania, jeśli dany typ wspólnoty ową ochroną objęty nie jest. Aby jej udzielić lub odmówić, trzeba najpierw nazwać konkretną wspólnotę i określić jej cechy. Dlatego niezależnie od tego, jak się sprawy potoczą, pewne jest, że kwestia rozumienia pojęcia „konkubinat" tudzież innych pojęć odnoszących się do związków nieformalnych będzie jeszcze nieraz poruszana, tak $\mathrm{w}$ doktrynie prawa, jak i w orzecznictwie.

\section{Bibliografia}

\section{Akty prawne}

Dekret z 25 września 1945 r. Prawo małżeńskie (Dz. U. Nr 48, poz. 270).

Francuski kodeks cywilny z 21 marca 1804 r. (Code civil), http://www.legifrance. gouv.fr/affichCode.

Ustawa z 25 lutego 1964 r. Kodeks rodzinny i opiekuńczy (t.j. Dz. U. z 2012 r., poz. 788$)$.

117 Por. F. Hartwich, Zwiazki partnerskie..., s. 79.

118 Ibidem. 
Ustawa z 23 kwietnia 1964 r. Kodeks cywilny (t.j. Dz. U. z 2014 r., poz. 121).

Ustawa z 17 maja 1989 r. o stosunku Państwa do Kościoła Katolickiego w Rzeczypospolitej Polskiej (t.j. Dz. U. z 2013 r., poz. 1169).

Ustawa z 24 stycznia 1991 r. o kombatantach oraz niektórych osobach będących ofiarami represji wojennych i okresu powojennego (t.j. Dz. U. z 2012 r., poz. 400).

Ustawa z 26 października 1995 r. o niektórych formach popierania budownictwa mieszkaniowego (t.j. Dz. U. z 2013 r., poz. 255 z późn. zm.).

Ustawa z 6 czerwca 1997 r. Kodeks karny (Dz. U. Nr 88, poz. 553 z późn. zm.).

Ustawa z 29 sierpnia 1997 r. Ordynacja podatkowa (t.j. Dz. U. z 2012 r., poz. 749 z późn. zm.).

Ustawa z 24 lipca 1998 r. o zmianie ustawy - Kodeks rodzinny i opiekuńczy, Kodeks postępowania cywilnego, Prawo o aktach stanu cywilnego, ustawy o stosunku Państwa do Kościoła Katolickiego w Rzeczpospolitej Polskiej oraz niektórych innych ustaw (Dz. U. Nr 117, poz. 757).

Ustawa z 22 stycznia 1999 r. o ochronie informacji niejawnych (t.j. Dz. U. z 2005 r., Nr 196, poz. 1631 z późn. zm.).

Ustawa z 12 marca 2004 r. o pomocy społecznej (t.j. Dz. U. z 2012 r., poz. 182 z późn. $\mathrm{zm}$.).

Ustawa z 5 sierpnia 2010 r. o ochronie informacji niejawnych (Dz. U. Nr 182, poz. 1228).

\section{Literatura}

Barlow A., Duncan S., James G., Park A., Cohabitation, Marriage and the Law. Social Change and Legal Reform in the 21st Century, Oxford - Portland 2005.

Ćwiek W., Konkubinat, Warszawa 2002.

Hartwich F., Konkubinat - dylematy prawne, „Palestra” 2007, nr 3-4.

Hartwich F., Zwiazki partnerskie. Aspekty prawne, Warszawa 2011.

Labbée X., Le droit commun du couple, Villeneuve d'Ascq 2012.

Litewski W., Słownik encyklopedyczny prawa rzymskiego, Kraków 1998.

Logika dla prawników. Słownik encyklopedyczny, red. A. Malinowski, Warszawa 2012.

Malaurie P., Fulchiron H., La Famille, Paris 2011.

Markowski A., Pawelec R., Wielki słownik wyrazów obcych i trudnych, Warszawa 2001.

Morawski L., Główne problemy współczesnej filozofii prawa. Prawo w toku przemian, Warszawa 2003.

Nazar M., Konkubinat, [w:] System Prawa Prywatnego. Prawo rodzinne i opiekuńcze, red. T. Smyczyński, t. XI, Warszawa 2009.

Nazar M., Konkubinat a mał̇̇eństwo - wybrane zagadnienia, [w:] Księga Jubileuszowa Profesora Tadeusza Smyczyńskiego, red. M. Andrzejewski, L. Kociucki, M. Łączkowska, A. N. Schulz, Toruń 2008. 
Nazar M. [w:] Prawo rodzinne, J. Ignatowicz, M. Nazar, Warszawa 2012.

Nazar M., Rozliczenia majątkowe konkubentów, Lublin 1993.

Newcomb P. R., Cohabitation, [w:] International Encyclopedia of the Social Sciences, ed. W. A. Darity Jr, t. 2: Cohabitation - Ethics in Experimentation, Detroit 2008.

Osuchowski W., Rzymskie prawo prywatne. Zarys wykładu, Warszawa 1981.

Pągowska E., Ratunek w latunku, „Polityka” 2008, nr 23.

Paul B., Konkubinat, "Jurysta” 2002, nr 7-8.

Paździor S., Konkubinat w prawie kanonicznym oraz polskim prawie cywilnym, „Roczniki Nauk Prawnych" 2007, t. XVII (2).

Pietrzykowski K., [w:] Kodeks rodzinny i opiekuńczy. Komentarz, red. K. Pietrzykowski, Warszawa 2012.

Romanowski M., Podział praw podmiotowych na majątkowe i niemajątkowe, "Państwo i Prawo" 2006, z. 3.

Slany K., Alternatywne formy życia mał̇̇eńsko-rodzinnego w ponowoczesnym świecie, Kraków 2002.

Słownik języka polskiego. t. I, A-K, red. H. Szkiłądź, S. Bik, C. Szkiłądź, Warszawa 1993.

Stownik Języka Polskiego PWN, http://sjp.pwn.pl/szukaj/konkubinat.

Smyczyński T., Małżeństwo - konkubinat - związek partnerski, [w:] Związki partnerskie. Debata na temat projektowanych zmian prawnych, red. M. Andrzejewski, Toruń 2013.

Sychowicz M., [w:] Kodeks rodzinny i opiekuńczy. Komentarz, red. K. Piasecki, Warszawa 2011.

Szer S., Konkubinat, „Studia Cywilistyczne” 1969, t. XIII-XIV.

Szlęzak A., Stosunki majątkowe między konkubentami. Zagadnienia wybrane, Poznań 1992.

Szlęzak A., Wybrane zagadnienia prawno-rodzinne konkubinatu, „Ruch Prawniczy Ekonomiczny i Socjologiczny" 1992, z. 3.

Wołoszko A., Cywilnoprawne zagadnienia konkubinatu, „Przegląd Policyjny” 1999, nr 4.

Zieliński A., Zarys instytucji konkubinatu, „Palestra” 1983, nr 12.

Ziembiński Z., Logika praktyczna, Warszawa 2009.

\section{Orzecznictwo}

Postanowienie SN z 7 lipca 2004 r., II KK 176/04, LEX nr 121668.

Wyrok NSA w Warszawie z 12 kwietnia 2000 r., V SA 1512/99, LEX nr 49058.

Wyrok SA w Białymstoku z 23 lutego 2007 r., I ACa 590/06, LEX nr 259105.

Wyrok SA w Białymstoku z 31 października 2012 r., I ACa 489/12, LEX nr 1235969.

Wyrok SA w Katowicach z 4 października 2012 r., II Aka 349/12, LEX nr 1236422.

Wyrok SN z 31 marca 1988 r., I KR 50/88, LEX nr 20315. 
Wyrok SN z 5 grudnia 1997 r., II CKN 485/97, LEX nr 583765.

Wyrok SN z 27 listopada 1998 r., II CKN 31/98, LEX nr 37571.

Wyrok SN z 26 października 2000 r., II CKN 956/99, LEX nr 45570.

Wyrok SN z 6 grudnia 2007 r., IV CSK 301/07, LEX nr 361309.

Wyrok Trybunału Sprawiedliwości z 17 lutego 1998 r., Grant v. South-West Trains Ltd, C-249/96, LEX nr 111552. 